\title{
The role of local energy initiatives in co-producing sustainable places
}

\author{
Diogo Soares da Silva ${ }^{1}\left[\right.$ : Lummina G. Horlings ${ }^{2}$
}

Received: 9 August 2019 / Accepted: 21 November 2019 / Published online: 3 December 2019

(c) The Author(s) 2019

\begin{abstract}
During the first two decades of the twenty-first century, the introduction of policies that promote renewable energy in Western European countries facilitated a shift towards the production of cleaner energy and its decentralisation. Subsidies, incentive schemes, and declining installation costs—combined with rapid technology advances—made the investment in small-scale solar photovoltaic (PV) panels and wind turbines more attractive for individuals and small businesses. Simultaneously, we observe the emergence of citizen initiatives which aim to provide public services across various sectors, including renewable energy generation and distribution. These initiatives, started by citizens, often involve the participation of local residents and prioritise social and environmental goals. In some areas, governments and engaged citizens work together to achieve common goals through citizen-government co-production. In this article, we address the question: how can the co-production of government(s) and citizens, through local energy initiatives, contribute to the shaping of more sustainable places? Using the PlaCI model — a conceptual model of citizen initiatives and their role in shaping sustainable places—we conduct an analysis of WindpowerNijmegen, a citizen-led renewable energy cooperative in the Netherlands. We assess who the relevant stakeholders are, what are the enabling conditions for fruitful collaboration, which new arrangements are established, and how they contribute to shaping more sustainable places. The results indicate that local energy initiatives are place based, conditioned by the characteristics of the physical space needed for the production of renewable energy, specific institutional arrangements, place-based assets and people's capacities characteristic for the place, and past collaboration.
\end{abstract}

Keywords Local energy initiatives · Citizen initiatives · Co-production · Governance · Energy transition · Sustainable place shaping

\section{Introduction}

To reduce greenhouse gas emissions, European Union (EU) countries have pledged to progressively decarbonise their energy production in the first decades of the twenty-first

Handled by Dirk Roep, Rural Sociology Group, Wageningen University and Research, Netherlands.

Diogo Soares da Silva

diogo.soaresdasilva@wur.nl

$\triangle$ Lummina G. Horlings

1 Rural Sociology Group, Wageningen University and Research, Hollandseweg 1, $6706 \mathrm{KN}$ Wageningen, The Netherlands

2 Department of Spatial Planning and Environment, Faculty of Spatial Sciences, University of Groningen, Mercator Building, Landleven 1, 9747 AD Groningen, The Netherlands century. The European Commission has a long-term aim of achieving a carbon-neutral economy by the year 2050 to reach the climate goals of the Paris Agreement. The EU's 2009 Renewable Energy Directive (RED) required the Union to produce $20 \%$ of its total energy needs via renewable sources (wind, solar, hydro, tidal, geothermal, and biomass) by 2020 .

A more ambitious 2018 revision of the RED establishes a binding target for renewable energy share in $32 \%$ in the year 2030. This new policy framework puts the consumer "at the centre of the energy transition with a clear right to produce own renewable energy" (European Commission 2018: 1) and is supposed to speed up bureaucracy procedures for permits and provide long-term certainty for investors in renewable projects. It explicitly mentions that this directive allows households, communities, and businesses to become clean energy producers. 
The recognition by the EU of the role of citizens, communities, and businesses in the transition to a low-carbon economy is in line with the surge in what authors and institutions call local energy initiatives (LEI), "citizen energy communities" (CEC) or "renewable energy sources cooperatives" (REScoops). In this article we refer to these initiatives as LEI. We define LEI as third sector citizenled initiatives focused on the decentralised generation of renewable energy (usually wind, solar, and micro-hydro), often community minded and not for profit (e.g. Arentsen and Bellekom 2014; Oteman et al. 2014; Coenen et al. 2017). Political and institutional support for such citizen initiatives is on the rise, with recent governments in countries such as the Netherlands and the UK promoting "active citizenship", empowering and encouraging citizens to play a more active role in their communities, relying less on governments (e.g. Marinetto 2003; Borgi and Berkel 2007; Perri 6 et al. 2010; Verhoeven and Tonkens 2013; Soares da Silva et al. 2018).

As of the beginning of 2019, more than 3400 LEI were active in Europe, representing more than a million European citizen investors (Derveaux 2019). These initiatives are seen as a grassroots way of contributing to a transition to a lowcarbon economy (Seyfang and Haxeltine 2012; Wierling et al. 2018; Soares da Silva et al. 2018; Hasanov et al. 2019). Local energy initiatives involve the participation of engaged local citizens, something authors such as Ornetzeder and Rohracher (2013) see as vital for a successful energy transition. Moreover, the goals of these LEI and local, regional, and national governments partly overlap, resulting in new forms of collaboration between citizens and governmenta process often defined as co-production (Marschall 2004; Verschuere et al. 2012; Albrechts 2012; Nesti 2017).

Additionally, as Wierling et al. (2018) point out, the recent rise of energy cooperatives follows the development of generous governmental support schemes, especially attractive feed-in tariffs (a policy mechanism through which long-term contracts to buy power at a fixed, above market price are offered to renewable energy projects). Technical progress and economies of scale made the investment costs of small-scale wind and solar PV (photovoltaic) installations more affordable for small players such as energy cooperatives. For example, available data from Germany (Fraunhofer ISE 2019) shows a 75\% decrease in the investment costs for a PV rooftop system between 2006 and 2018. However, it is also worth noting that the termination of governmental support schemes may pose a risk to the financial viability of existing cooperatives, especially if their portfolios are not diversified (Wierling et al. 2018).

Country-wise, the Netherlands makes an interesting case for reflection. The country benefits from a politically supportive environment for active citizenship (Hajer 2011; Verhoeven and Tonkens 2013) and boasts a total of 484 active energy cooperatives as of November 2018 (HIER Opgewekt 2018). However, it is also the EU country that is the furthest away from its national 2020 target in terms of share of energy from renewable sources in their gross final consumption of energy (Eurostat 2019). Although the share of energy from renewable sources is projected to rise, the country still lags behind its European counterparts. Wind and solar represent only $2.3 \%$ of all energy consumed in the Netherlands. Although this share has been growing in the past 20 years, they represent only roughly 48 of the 2100 petajoules (PJ) consumed annually by the Dutch.

In this article, we analyse a Dutch local energy initiative using an adapted version of the PlaCI model-a conceptual model of citizen initiatives and its role in shaping sustainable places (Soares da Silva et al. 2018). The initiative, WindpowerNijmegen, is one of three LEI analysed in a wider research project through a case study approach, conducted in 2018 and 2019. Data collection included the analysis of grey literature such as reports and policy documents. In-depth, semi-structured interviews were held with key individuals who initiated or are involved in the cooperative. Our central research question is: how can the co-production of government(s) and citizens, through local energy initiatives, contribute to the shaping of more sustainable places?

Sustainable place shaping refers to the capacity of citizens to develop sustainable practices that shape their living environment according to their own ideas, needs, values, and demands. The theoretical assumption here is that places are continuously shaped through ecological, political, and socio-cultural transformation processes, but also by the agency of people capable of changing these dynamics (Roep et al. 2015; Horlings 2016). We discuss the role of LEI as a possible pathway for energy transition, assess who the relevant stakeholders are, and analyse the enabling conditions for fruitful collaboration with governments and how new arrangements are established. The objective is to provide insight into the conditions for coproduction that supports sustainable place shaping.

The structure of this paper is as follows. We first provide the context of this study and explore the role of local energy initiatives in energy transition and how they can contribute to the shaping of more sustainable places via co-production with governmental actors. We illustrate this by describing the results of the case study of WindpowerNijmegen. In the last two sections, we engage in a discussion on the outcomes of the research and end with conclusions. 


\section{Sustainable place shaping and energy transition}

The urgency for energy transition has become clear in the wider debates on the depletion of fossil resources and climate change. The simple evidence of a global ambient temperature rise is indisputable. The most cautious models of the International Panel on Climate Change (IPCC) predict that "global warming is likely to reach $1.5^{\circ} \mathrm{C}$ between 2030 and 2052 if it continues to increase at the current rate" (International Panel on Climate Change 2018: 4). According to the IPCC, the effects of climate change will also result in robust differences in regional climate characteristics. These differences include increases in: mean temperature in most land and ocean regions, hot extremes in most inhabited regions, heavy precipitation in several regions, and the probability of drought and precipitation deficits in some regions (International Panel on Climate Change 2018). The rise of $\mathrm{CO}_{2}$ emissions, combined with the melting of the Arctic ice, the methane-releasing thawing of permafrost in the North Pole area, the rise in sea water levels, and all sorts of feedback loops, will result in non-linear changes (Bendell 2018; Wallace-Wells 2019). These changes take place at a rapid pace, which leaves governments with a very limited window of opportunity to take measures in reducing $\mathrm{CO}_{2}$ emissions. As a response, energy policies to reduce $\mathrm{CO}_{2}$ emissions and to support renewable energies are quickly gaining more urgency and momentum as part of the political agenda, especially in Western European countries.

It has been stated that the ability to adapt effectively to the current environmental vulnerabilities asks for an inherently sustainable and 'place-based' approach and interdisciplinary solutions, building on the specific resources, assets, capacities, and distinctiveness of places (Horlings 2018). Place is a bridging notion that reinforces the integrating and interactive relations between humans and their environment (Marsden 2013). The place-based research lens can also strengthen different disciplinary views to understand the transformative role of sustainable practices to address the challenge of energy transition. However, more research is needed to answer questions such as what motivates people to transform (needs), what should be transformed (challenges), how to transform (via innovations, arrangements) and through which practices can transformation be achieved.

Climate change and energy transition are not just environmental challenges, but inherently political, societal, and spatialised issues. Societal, in the sense that humans have to 'deeply adapt' to climate change, includes the emotional and psychological attitudes needed to change awareness, attitudes and behaviours (Bendell 2018). Spatial, in the sense that $\mathrm{CO}_{2}$ emissions have specific multi-scale dimensions in terms of causes, impacts and potential for solutions. This calls for a transcendence of local-global divisions (see also Massey 2005).

Our assumption is that the concepts of place and sustainable place shaping help us to address the multi-scalar dimensions of energy transition. We consider sustainability here as a 'balancing act' between planet, people, and profit. Embodied in international policy agendas starting from the 1972 Stockholm Conference, the best-known formal definition of the concept is contained in the socalled Brundtland Report 'Our Common Future' (WCED 1987). In this report, sustainable development is defined as development that meets the needs of the present without compromising the ability of future generations to meet their own needs. This definition addresses the 'here and now' as well as the 'there and then'. However, in sustainability debates, the connections between sustainability and notions of space and place often remain implicit and underestimated (Horlings 2019).

We consider place here as an assemblage of actors (Woods 2015) or 'throwntogetherness' (Massey 2005), pointing to the relevance of social relations stretching beyond administrative boundaries. This builds on a relational conceptualisation of space and place (Amin 2004; Cresswell 2004; Jones 2009; Massey 2005; Woods 2011; Varró and Lagendijk 2013), as the constantly unfolding product of flows and networks.

A 'politics of connectivity' (Amin 2004; Horlings 2018) acknowledges place as the dynamic outcome of a multiplicity of relations (Woods 2011) and as an arena of place-based debates, power struggles, and negotiations (Horlings 2018). Such place-based struggles result from local agency, able to alter the very mechanisms of the global itself (Massey 2004). A relational approach thus emphasises the multi-scalar dimensions of practices beyond geographical or administrative boundaries.

Sustainable place shaping is defined here as the capacity to localise and embed daily lived practices in social-ecological systems and place-based assets, thus altering the relations between people and their environment (Horlings 2019). This perspective acknowledges that structuring ecological, political, and social-cultural relations shape places, but also that people are able to alter these relations on multiple scales (Horlings 2016). Innovative socio-spatial practices can provide an interface between people and places where self-efficacy, local values, and deviance from unsustainable practices can lead to sustainable place shaping. In this paper, we show that a place-based approach to fostering the 'energy transition' has potential to help understand how innovative sustainable energy initiatives may contribute to the energy transition. 


\section{Co-production between public authorities and local energy initiatives}

The governance of places undergoes radical changes brought about by the necessary shift towards renewable energy, raising questions that can and should take the lead in energy transition. Our hypothesis is that the co-production of governments and initiatives can potentially result in shared leadership in solving the challenges in energy transition.

Citizen initiatives recently have taken up an active leadership role in the production of renewable energy, contributing to socio-spatial transformation (Hawkins and Wang 2012; Igalla and Van Meerkerk 2015). Filling the gaps left by the public and private sectors, they take matters into their own hands (Elzenga and Schwenke 2015). The engagement of citizens is part of a trend which has been termed by scholars and policy makers in various ways, e.g. the 'do-democracy' (Van de Wijdeven and de Graaf 2014), the 'sharing economy', the 'energetic society' (Hajer 2011), or the 'participative' (Tonkens 2008) or 'participation society' (Movisie 2017), thus describing empowered and knowledgeable citizens with reaction speed, learning ability and creativity, willing to be actively involved in creating and contributing to their own environment (Hajer 2011). Citizen initiatives are seen as a type of bottom-up movement in which individuals collaborate to "take the lead in managing their living environments" (de Haan 2019: 2).

Active citizenship has become popular among scientists who have used different concepts to understand these phenomena, such as transformative agency (Westley et al. 2013), grassroots innovation (Seyfang and Smith 2007), social innovation (Moulaert and Mehmood 2011; Bock 2012) or niche innovation (Kemp et al. 2001; Geels 2004), the democratic power of associations (Warren 2001), active citizenship (Van Dam et al. 2014), bottomup development (Miazzo and Kee 2014), self-organisation (Boonstra and Boelens 2011), or the silent revolution of collective action (De Moor 2008).

Here, we use the term local energy initiatives (LEI), following the definition of Oteman et al. (2014: 2): "decentralized, non-governmental initiatives of local communities and citizens to promote the production and consumption of renewable energy". These third sector initiatives are seen as drivers of innovation (Hielscher et al. 2011). The motives of people to start this are manifold and are not the same for everyone who chooses to participate in an LEI. These can be political (dissatisfaction with governmental policies), environmental (climate change concerns), social (community building), and/or purely economic (e.g. Hoppe et al. 2015).

Local energy initiatives play multiple roles in the transition towards a low-carbon economy, not only through the production of clean energy but also through community building, organising protests, provision of expertise, and promoting sustainability (Smith 2012). However, these initiatives face a variety of challenges, such as complicated access to funding (Guillou 2019) and institutional support, the dependency on volunteers for their daily activities, a shortage of full-time skilled individuals, and a lack of an established infrastructure of assistance and support (Hoppe et al. 2015).

In the Netherlands, some pioneering LEI were established in the 1980s and 1990s, mostly rooted in concerns around oil crises and the anti-nuclear movement. The process of liberalisation of the Dutch energy sector in the early 2000s, along with environmental concerns and a dissatisfaction with the lack of continuity in energy policies, has triggered the emergence of a new wave of initiatives (Oteman et al. 2017). Three large retailers have $80 \%$ of the energy market share (Mulder and Willems 2019), following the entrance of large international energy conglomerates in the Dutch market. However, the liberalised market—along with the establishment of net metering rules and declining installation costs of solar panels - has also enabled the growth of local energy initiatives. The 2018 report by 'HIER opgewekt', an organisation that provides a knowledge platform for LEI, lists 484 active initiatives in the country, 85 more than in 2017 (HIER Opgewekt 2018).

Still, despite the growing number of LEI, if action towards climate change mitigation is to be taken by actors at different levels, from groups of citizens to supra-national organisations, some degree of coordination between them is vital (e.g. Biesbroek et al. 2009; Meijerink and Stiller 2013). This raises questions on citizen-government dynamics and the role of citizens in governance (Van Dam et al. 2014). Despite the more active role of citizens in energy production, we have to acknowledge the essential role of governmental actors and public policies in tackling and managing the effects of climate change (Meijerink and Stiller 2013). Government and citizens can work together, creating new institutional arrangements through co-production, resulting in a shift from 'government-led to community-led' spatial planning (Meijer 2018; Soares da Silva et al. 2018).

We assume co-production is a key factor for building new institutional arrangements that can facilitate this transformation. Co-production, as defined by Ostrom (1996: 1079), is "the process through which inputs used to produce a good or service are contributed by individuals who are not in the same organisation", generating synergy between the actions of governments and citizens, with citizens taking an active role, not a merely consultative one. Verschuere et al. (2012) refer to co-production as the involvement of individuals or groups of citizens in the delivery of public services. Albrechts (2012) adds that equal partnership must exist between the multiple actors, shifting the balance of 
power, responsibility of resources from professionals to individuals and collectives that engage in shaping their own places. Nesti (2017) found that co-production between citizens and government can improve the quality of services. Other authors argue for its importance in the management of social change (e.g. Baker and Mehmood 2015). As Whitaker argued (1980), social change itself depends on the co-production of citizens and grassroots organisations that create the dynamics which enable transformative practices.

As Sorrentino et al. (2018) put it, co-production is a public governance tool. As a form of governance, citizen-led initiatives such as LEI fit into Driessen et al. (2012)'s definition of 'self-governance', in which the initiative is started by civil society and/or the private sector and may or may not interact with the public sector. In such cases, public institutions are expected to have a supporting or background role (Soares da Silva et al. 2018). Although this is often the case when it comes to the establishment of the initiative, institutional actors can still play a central role both as a resourceful actor and as a facilitator in various phases of the process (Sorrentino et al. 2018).

However, co-production has also its risks. Common downsides of co-production in LEI-especially when governmental support schemes are involved-are, for example, the risk of dependence on governmental resources, fragility to sudden political changes, policy shifts, and budget cuts (Seyfang and Smith 2007). De Haan (2019) points out two more obstacles that can inhibit successful collaboration between citizens and institutions. One of them is the difference in pace between the action of citizens and that of institutional bureaucratic processes. The other refers to issues of scale, since government officials are often required to respond to issues at a higher scale (regional or national) than citizens, who tend to mostly act at the local level.

Top-down support for these initiatives might result in a transfer of responsibilities towards citizens, as Meijer (2018) mentions. However, there is the risk of co-optation or institutionalisation stemming from imbalances between citizens and institutions. This might tone down their values and deteriorate the relationship with local communities (Coy and Hedeen 2005).

The practices of citizen initiatives in general, and LEI in particular, have also been linked to notions of institutional and social innovation due to their enabling of institutional interactions across sectors and scales (e.g. de Boer et al. 2018). Social innovations are ideas that meet social needs and create new social relationships or collaborations (European Commission 2010), going beyond meanings of innovation that are mainly of technological nature. Social innovation has been interpreted by scholars in different ways, although most definitions of social innovation share commonalities such as (a) social mechanisms of innovations, (b) social responsibility of innovations, and (c) the innovation of society (Bock 2012). As Moulaert et al. (2013) point out, social innovations have the potential to enhance the capacities of citizens to act and form bottom-up social movements that can improve communities. Citizen initiatives mobilise resources which potentially can contribute to social innovation and new institutional arrangements (Horlings 2017; Ulug and Horlings 2019). They might have a transformative potential where they operate through upscaling their practices or influencing their social and institutional environment (Hasanov et al. 2019).

\section{A model of citizen initiatives and their role in shaping sustainable places}

In the model below, we consider co-production in the context of place, emphasising the role of people in making, shaping and keeping places, while also collaborating with governments on multiple scales. Place can thus be a site of incubation and spatial networking to promote energy initiatives and innovation. Human agency potentially acts as an initiator of sustainable place shaping by shifting boundaries, establishing links between different spatial scales and communities (upscaling), and building new relations.

Our theoretical framework is an adapted version of the PlaCI conceptual model of citizen initiatives and their role in shaping sustainable places through collaboration with institutions. The PlaCI model is explained in great detail in Soares da Silva et al. (2018). It builds on two other models: the analytical framework for describing processes of enabling of collective action developed by Bakker et al. (2012) and its expanded version developed by Denters (2016). Bakker et al.'s framework is based on the Institutional Analysis and Development framework (Ostrom 1990, 2005, 2011), on a review of collaborative governance cases by Ansell and Gash (2007), and includes Lowndes et al. (2006)'s CLEAR model, a model that clusters factors that explain civic participation. Denters' version, the ACTIE model, adapts it further to assess the success and failure of citizen initiatives, assessing not only the motivations and resources available to citizens, but also systemic factors related to cultural, administrative, and political aspects of the place where these initiatives operate. As a consequence of the relational approach to place, Soares da Silva et al. (2018) have added exogenous variables that influence the interactions between citizens and institutions and which inform the co-production of policies and services, such as the history of collaboration between citizen and institution, and more place-based features of the territory where the initiatives act (physical, geographical, geopolitical). The PlaCI model is a systems map that acknowledges both local and global economic and social conditions that might trigger or influence the determination of citizens to act, as well as the agency of initiatives 
in places. This is especially important when conducting a cross-region or cross-country comparison, as place is recognised as the arena where the co-production of policies and services happens. While the original PlaCI model features a series of potential outcomes, the revised model presented in Fig. 1 focuses on sustainable place shaping as an outcome of co-production.

The underlying hypothesis derived from this revised model is that the co-production between citizens and institutions, under these enabling conditions, can result in the development of practices and processes that support sustainable place shaping. These practices, if relevant, feed into possible new arrangements, effectively changing the history of past collaboration between citizens and institutions, and serving as a good practice of social innovation that can be adapted or replicated elsewhere.

\section{Methods}

In the context of a wider research project on citizen initiatives, three initiatives in three different EU member states were chosen as case studies (Soares da Silva et al. 2018) in the wider context of SUSPLACE (an acronym for sustainable place shaping), a European Marie Curie (ITN) funding scheme for Innovative Training Networks funded by the European Commission. The researcher chose to take on a

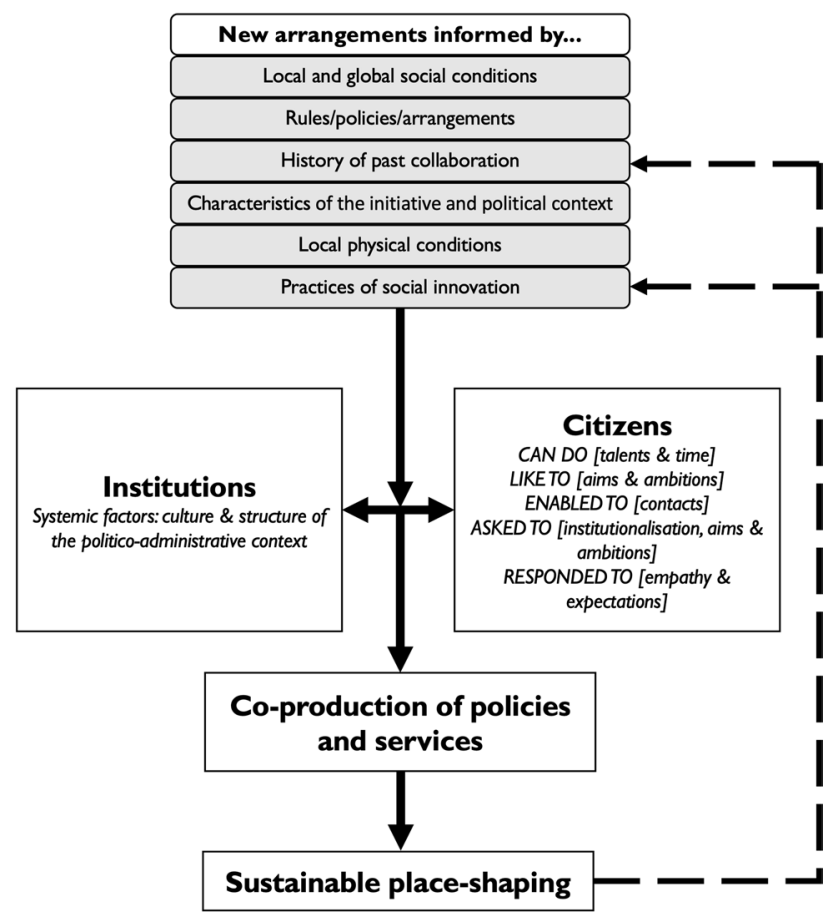

Fig. 1 Co-production of citizens and institutions for sustainable place shaping role as reflective scientist (see an overview of roles in Wittmeyer and Schäpke 2014). This entails collecting, analysing, and interpreting data in an observant, "conventional" way of doing research, striving for validity and repeatability of the study.

The three initiatives were selected due to the fact that they all operate in the same sector-the small-scale production of renewable energy. This allows for a cross-country comparison. Another criterion was the fact that the initiatives were initiated by citizens, so independently from companies or public institutions. In this article, we focus on the specific case of WindpowerNijmegen, an energy cooperative based in the municipality of Nijmegen, in the east of the Netherlands. This initiative was selected because it offers an interesting case to understand how specifically co-production takes place between government and citizens in the context of decentralised policies. It was also chosen over the other two case studies given the peculiar case of the Netherlands in the European context: a country that despite its politically supportive environment for citizen action (and, therefore, the establishment of LEI) lags behind most of its counterparts when it comes to production and consumption of energy from renewable sources. A cross-case comparison will be featured in a forthcoming paper.

With regard to the data collection, along with an analysis of policy documents, reports, and other primary and secondary sources, in-depth interviews with two of the main actors of the initiative were conducted face to face between August and October 2018. These interviews, ranging from 59 to 70 min long, were supported by a semi-structured interview guide, and the interviewed individuals were selected via the contact person of the initiative. One of the interviewees was one of the starters of the initiative, and the other has been a board member since the early days of the project. The interview guide contains open-ended questions, linked to the motivations for setting up the initiative, its history and timeline, their interactions with other institutions and residents, and the energy sector in the Netherlands. These interviews were recorded, transcribed, and then analysed through the lens of the PlaCI model.

\section{Case study: cooperative WindpowerNijmegen}

Coöperatie WindpowerNijmegen is a citizen-owned energy cooperative based in Nijmegen, the largest city in the eastern province of Gelderland, in the Netherlands. It was established in 2013, following an informal meeting between citizens at a Klimaatstraatfeest (a climate street party) event in Nijmegen. The cooperative built Windpark Nijmegen-Betuwe, composed of four turbines in municipality-owned land along the A15 motorway, in the north of 
the municipality. It was successfully funded by 2015 and completed in 2016. The cooperative has more than 1400 members, and more than 1000 urban residents in the city of Nijmegen helped funding the wind park through the purchase of shares (windaandelen). While many renewable energy cooperatives, as market actors, do not prioritise attracting a mainly local membership base, around $90 \%$ of the members who have purchased shares, in this case, live in the area of the Rijk van Nijmegen, comprising the city itself and the surrounding municipalities. It is composed of a board, investors, and non-investing members. The four turbines produce enough energy to power 7100 households. As of 2019, the cooperative is planning to construct solar park Zonnepark de Grift, a complex of 17,000 solar panels to be built in the same site as Windpark Nijmegen-Betuwe. This solar park is expected to power an additional 1245 households, generating an average of $4.4 \mathrm{GWh}$ energy per year.

Several stakeholders played a part in the development, management, and financing of the operations of Coöperatie WindpowerNijmegen (Fig. 2). The foundation Stichting Wiek-II was developed in parallel with the cooperative with the mission to develop community projects for local initiatives. It is a collaboration between WindpowerNijmegen, the regional association Gelderse Natuur- en Milieufederatie (an environmental NGO), and the local company Izzy Projects. The foundation is managed by a three-person board with equal representation from the three organisations. As the cooperative is volunteer based, Stichting Wiek-II was vital to its success by providing not only expertise in energy projects, but also the access to an extended network of professionals. Stichting Wiek-II was thus responsible for the initial development of the project of Windpark Nijmegen-Betuwe, including the contracts for the financing of the project, handing over the ownership of the wind park to the cooperative at the end of 2016, and serving as support from then on.

On the financial side, besides a bank loan and the two million euros raised by the citizen investors, three institutions were key in making the project successful. The municipality of Nijmegen has loaned both the initial sum for operational expenses-if the project did not succeed, it would not have to be paid back-and the land in which the four turbines were built. During the development of the wind park, the municipality has also covered specific development costs. Oost $N L$ - the East Netherlands Development Agency-co-financed the construction of the windmills via the provincial Innovatie- en Energiefonds Gelderland (IEG), It owns 5\% of the Windpark shares for the first 5 years of operation of the wind park. The ministry has also supported the project financially through its incentive scheme for sustainable energy production, Stimulering Duurzame Energieproductie (SDE+). Through $\mathrm{SDE}+$, WindpowerNijmegen is compensated annually, for a period of 15 years, for the difference between the cost price of the produced energy and the price for which it is sold in the market.

\section{Results}

In this section, we assess the case of WindpowerNijmegen through an analysis of the conditions that can enable a fruitful co-production between citizen-led initiatives and their institutional partners. See Table 1 for an overview of the enabling conditions for co-production.
Fig. 2 WindpowerNijmegen and Windpark Nijmegen-Betuwe organisational chart

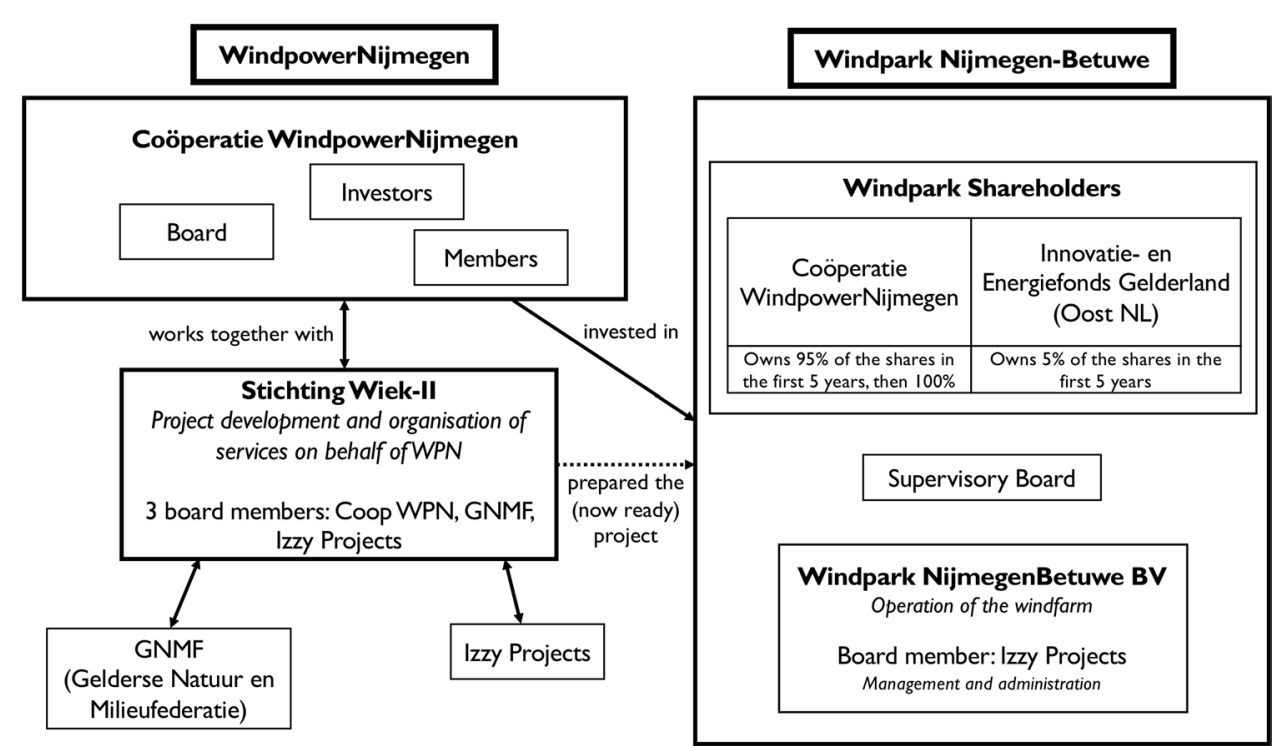


Table 1 Conditions for citizen-institution co-production in the case of WindpowerNijmegen

\begin{tabular}{ll}
\hline Informed by... & WindpowerNijmegen \\
\hline Local/global social conditions & $\begin{array}{l}\text { Strong institutional support for citizen participation at the national level } \\
\text { No significant local opposition to the wind park }\end{array}$ \\
$\begin{array}{l}\text { Rules/policies/arrangements } \\
\text { Institutional and financial support from all layers of government: municipal, regional and national }\end{array}$ \\
$\begin{array}{ll}\text { History of past collaboration } \\
\text { Nature of the initiative (green } \\
\text { energy production) }\end{array}$ & $\begin{array}{c}\text { Nijmegen was the European Green Capital of 2018. Widespread citizen support for green politics and green } \\
\text { initiatives in the city }\end{array}$ \\
Local physical conditions & $\begin{array}{c}\text { Plans for the area included wind energy since the mid-90s. The land where the wind turbines are on is owned by } \\
\text { the municipality }\end{array}$ \\
Practices of social innovation & $\begin{array}{c}\text { Benefits of having initiators with past experience developing wind projects } \\
\text { Membership in a regional cooperative network to learn from more established cooperatives, but not in national } \\
\text { and international networks } \\
\text { Participation in networking events } \\
\text { New links between citizens, new rural-urban relations }\end{array}$ \\
\hline
\end{tabular}

\section{Local and global social conditions}

WindpowerNijmegen has benefitted from a strong institutional support for citizen-led initiatives. At the national level, the Social Support Act, often called 'participation law', shifts responsibilities and roles from the central to the local government and from government to citizens, stimulating active citizenship as the state retreats and calls for citizens to take a more active role in society. Although this discourse is criticised by some authors (e.g. Verhoeven and Tonkens 2013) for putting unnecessary burden on citizens and not being accompanied by a meaningful budget or support programs, this discourse still shapes an environment where citizens feel empowered (or compelled) to act and start their own initiatives. One of the interviewed members of the cooperative acknowledges this by mentioning that the "local government and Dutch government want to empower people more and more, combined with community initiatives that sprout".

At the neighbourhood level, some residents of one of the nearby villages were initially concerned with the construction of the wind park. They saw it as another major construction that could negatively affect their surroundings after seeing a highway, a railway, and a large industrial area being built in an area which used to be very quiet. Ultimately, after a series of informal talks with the residents, there was no significant formal opposition to the construction of the wind park, and the cooperative has reached an agreement with the residents who live closest to the wind park. In addition, for every $1 \mathrm{MWh}$ of energy produced in the windfarm, Windpark Nijmegen-Betuwe gives $€ 1$ to its Omgevingsfonds (environmental fund). This money is then used to fund collective projects for the benefit of residents that live within one-and-a-half kilometres away from the wind park.

\section{Rules, policies, and arrangements}

As mentioned above, at the national level, WindpowerNijmegen has benefitted from the SDE+ incentive scheme and a favourable environment for the support of bottom-up initiatives led by citizens. Regionally, the Gelderland and Overijssel agency Oost NL has also contributed financially to the funding of the wind park. But the main institutional support came from the municipality of Nijmegen, which financed important operations such as the mandatory environmental impact assessment, a small loan to kickstart the cooperative's operations, and rented out the plot where the wind turbines were built. Decentralising and devolving responsibilities to municipalities and their citizens seems to be typical of policies in the province of Gelderland compared to other Dutch provinces which follow a more top-down policy (Van Aalderen 2018). In fact, the province of Gelderland seemed to be mostly absent during the whole process, although they supported the initiative financially, because their intervention was not required, since the municipality and the initiative could deal with the process themselves.

\section{History of past collaboration}

Given that Coöperatie WindpowerNijmegen was established for the construction of the wind park, there was no previous collaboration between the cooperative and the involved governmental institutions. However, one of the initiators works for the Foundation for Nature and Environment of Gelderland (GNMF), an umbrella regional NGO which works closely with the province of Gelderland. Although the province was not directly involved in the process of building the wind farm, the know-how gathered in this established organisation with ties to the province has played a role in the success of WindpowerNijmegen: "What we did have 
were these people who took the initiative: one was from the GNMF, the environmental federation, and the other one was a wind developer, so we also [gained] a lot of knowledge from them for project development and the community projects we did".

\section{Characteristics of the initiative and political context}

The fact that Nijmegen was elected the European Green Capital of 2018, and aims to become carbon neutral by 2045, shows the commitment of the municipality towards sustainability. The municipality has a positive attitude towards establishing partnerships with other organisations: via the motto "doing green together", the municipality involves "enthusiastic and active organisations" and "embraces green initiatives". Nijmegen European Green Capital 2018 is a network of more than a hundred partners. Their goal is to become a role model for European medium-sized cities and developing sustainability "in and around" Nijmegen after 2018 (Nijmegen European Green Capital Programme 2017).

As one interviewee points out, the election of Nijmegen as European Green Capital is "illustrative of the whole panorama in the city", with citizens being "quite in favour" of environmental politics. They also argue that it would be "harder" to be successful as a green initiative if the city and its region were "less green or less progressive", albeit "not impossible". Nijmegen is, politically, one of the most leftwing cities in the Netherlands.

\section{Local physical conditions}

According to one of the interviewees, municipal plans for the area included the production of wind energy "since the mid-90s", with a designated area for the construction of a wind park, owned by the municipality. After a failed tentative plan-in partnership with energy company Eneco-of building a wind park in the first decade of the twenty-first century, the municipality was keen on pursuing the original plans for the area. This fact positively influenced the success of the initiative. The municipality-owned plots of land were then rented out to WindpowerNijmegen, which ensured that the project would be completed.

\section{Practices of social innovation}

The initiative is considered as an example of social innovation based on the definition of Bock (2012), as it is an example of social responsibility of citizens changing social mechanisms such as the relation between actors involved in energy transition, while also supporting institutional innovation by building public-private arrangements. National and international networks of cooperatives raise the profile of LEI, representing and allowing them to have a voice in conversations about policy on a national or supranational level. They are also a platform for mutual support and exchange of best practices and experiences between LEI (Huybrechts et al. 2018). One of the interviewees acknowledges the importance of being part of such networks, although WindpowerNijmegen is currently not affiliated to the Dutch network ODE Decentraal or the European Federation for renewable energy cooperatives, RESCoop.eu: "I find it important to become a member of that because together we can also lobby in The Hague and share knowledge". Instead, the cooperative is part of Vereniging Energie Coöperaties Gelderland (VECG), an association of energy cooperatives in the province of Gelderland. In addition, WindpowerNijmegen is also often present at the yearly HIER Opgewekt event that facilitates the establishment of contacts with other cooperatives. Moreover, some of the initiators already had multi-scale contacts and experience in the energy field.

The project has replicated best practices of social innovation by creating new links between like-minded citizens: in the beginning, the cooperative had only 30 members, growing to 350 in 2015, to 1013 when the project was finally funded, and to around 1400 as of 2019 . The dialogue established with residents in nearby villages has also helped to create new relations within the area, especially between city dwellers (favourable to the project) and villagers (who were concerned with the project). One of the initiators mentions that through the community engagement, people who live in the area became interested in energy and sustainability issues, even though they were first against the project. The local residents, from the four nearby villages of Reeth, Oosterhout, Nijmegen-Oosterhout, and Ressen, will also benefit from funds coming from the abovementioned Omgevingsfonds. This fund has financed the first seven projects in the fall of 2018.

\section{Discussion}

\section{Co-production and place-based development}

Co-production is considered as collaboration between initiatives/cooperatives and government shaping places (Meijer 2018). While LEI have shifted this collaboration towards self-governance, often initiating an initiative independently from any third party, they can still be considered forms of co-production, as they are dependent on some form of governmental support. In this case, governmental institutions from the municipal to the national level were involved. The municipality was responsible for some small loans, including the plot where the turbines were built; the province of Gelderland contributed with important funding via their Oost NL agency; at the national level, WindpowerNijmegen is funded through the SDE+ incentive scheme. 
Our findings show that co-production can involve multiple actors, as this initiative was the result of the cooperation between citizens and other organisations-such as private organisations and NGOs-and they can be embedded in the organisation of the cooperative itself. In this case, the provincial agency Oost NL is-although temporarily-one of the shareholders, via the Innovation and Energy Fund that financially supports the wind park, and both the association GNMF and the company Izzy Projects are members of the foundation who support the cooperative.

Co-production occurs on different scales. The wind park was supported via co-financing, providing land, and spatial planning policies on the local, regional scale, and national scale.

Our findings also point to the role of umbrella organisations in co-production in the context of energy transition from the local to the European scale. In our case, Stichting Wiek-II (local) the Vereniging Energie Coöperaties Gelderland (provincial), Dutch network ODE Decentraal (national), or the European federation for renewable energy cooperatives, RESCoop.eu, function as umbrella organisations that support LEI. This is also the case in other Dutch provinces (Van Aalderen 2018). Existing literature points to the crucial role of umbrella and intermediary organisations in local and regional development via their role as boundary spanners between grassroot development initiatives and public administration, as knowledge brokers, and by enabling citizens initiatives in upscaling and outscaling their innovative capacity (Hargreaves et al. 2013; Wellbrock 2013; Horlings et al. 2018).

Co-production resulted in new arrangements. On the one hand, the local physical and institutional context is crucial for establishing renewable energy practices. On the national level, the political setting and national goals set the bar for renewable energy production, while the implementation is decentralised to lower levels of governance.

Gelderland's decentralisation strategy appears to be effective in enabling and simplifying processes for grassroots organisations which are willing to invest in wind energy production. However, devolving tasks and responsibilities to the local level also has its downsides, as this has not helped the province to reach - so far-its share of a total of $6000 \mathrm{MW}$ onshore wind capacity set in the Dutch Energieakkoord as a goal for 2020. The province is set to fail its $230.5 \mathrm{MW}$ target-the lowest negotiated target of all Dutch provinces. Other provinces with a more rigid, top-down approach and higher targets, such as Noord-Holland, seem to be more effective (Van Aalderen 2018).

One of our assumptions was that the history of past collaboration can support arrangements between actors in new fields such as renewable energy production, inspired by literature on the role of path dependency in place-based innovation (Horlings et al. 2017). In this case, there was no history of past collaboration. However, the connectivity of specific actors, working as 'place leaders', helped to span boundaries between scales and actors. This corresponds with studies on the role of leading individuals or place leaders in bridging scales, crossing rural-urban boundaries, and spatial networking (Sotarauta et al. 2012; Horlings et al. 2018).

The initiative was embedded in a network of professional actors since its inception, with no need for additional technical expertise from local government. This, combined with favourable policies and subsidies from top levels of governance, has reduced the need for the municipality of Nijmegen to play a bigger role in the success of the initiative. However, although the municipality did not have to provide significant funding and technical expertise, the main institutional support came from the local government, as they provided a small loan to kickstart operations and loaned the plot in which the wind turbines were built.

Scholars have argued that place-based approaches to local and regional development based on the utilisation of endogenous assets, including knowledge and place-based institutions associated with a particular locality, "offer the scope for developing strategies that better represent tailormade policy actions embedded in, and linked to the specific needs and available resources of a locality" (Hildreth and Bailey 2014; cited in Bentley and Pugalis 2014: 284). A place-based approach acknowledges that embedded, multiscalar, and multi-annual strategies for development need to be tailored to the complex geographies, capabilities, knowledge sets, assets, and resources of particular places (and networks of places), through supportive institutional frameworks and collaborative means of governance (Bentley and Pugalis 2014). This rests on the claim that a region's capacity to innovate is conditioned by the quality of regional institutions (Rodríguez-Pose and Di Cataldo 2015). In our case, we found that devolution of tasks from the national to the regional and from the regional to the local level has profoundly influenced the current interest in place-based development. The mix of institutions in this case, their role, and their capacity to collaborate were enabling conditions for co-production in the establishment and success of the wind park. WindpowerNijmegen seems to have largely benefitted from a very favourable conjuncture: strong financial backing and facilitation from various institutional actors at the national, regional and local scale, and a progressive environment that favours green energy projects. Simultaneously, it has also benefitted from the absence of the most common obstacles to citizens initiatives as described by de Haan (2019: 96): the feeling that the initiators do not represent the community, volunteer burnout, a scale which is too large to operate in, lack of funding, a bad relationship between citizens and government, and conflicting and unaligned policies. All these factors seem to indicate that 
the case of WindpowerNijmegen might be an atypical case whose conclusions may not be generalised.

\section{Sustainable place shaping}

Sustainable place shaping results from social relations and connectivities which are expressed via practices. The practices of producing renewable energies in this case are grounded in place-based assets and capacities, and reposition the markets on renewable energy by shifting the responsibilities from large private companies to local energy initiatives. Place shaping has manifested itself here materially (the building of four large wind turbines), immaterially (via new relations between actors involved), and by establishing new rural-urban relations. While citizens of Nijmegen co-invested in the cooperative, revenues also benefitted the residents of the nearby villages. This has contributed to the sustainability of this rural-urban area. The initiative, like many local energy initiatives, primarily pursued a local sustainable agenda, addressing local characteristics and specific local problems, though not addressing sustainability issues beyond energy or on the (inter)national scale.

Local energy initiatives can potentially be economically profitable for some, but socially negative for others living in the vicinity of the local energy facility. However, in this case we witnessed the absence of a strong 'NIMBY' ("not in my backyard") sentiment and mobilisation amongst residents of neighbouring villages, which is a known fail factor of LEI (e.g. Eitan et al. 2019). This has also contributed to the success of the initiative. The extent until this will result in more sustainability practices is, however, yet to be seen. The results, however, indicate that LEI can play a role in developing pathways towards sustainable energy.

\section{The role of LEI as pathway for energy transition}

As described before, the Netherlands has an increasing number of LEI and benefits from a supportive environment (both governmental and in civil society) for a transition to a sustainable energy system (van der Schoor and Scholtens 2015; Hasanov and Zuidema 2018; HIER Opgewekt 2018; van Aalderen 2018). However, even with the development of support schemes and a laissez faire approach to citizen participation, it has largely failed to capitalise on its favourable conditions for a successful transition.

It is debatable what their actual impact is and can be. Wierling et al. (2018: 21) claim that LEI are important in transition, but recognise that there are no data available on the share of energy actually produced by LEI. A CE Delft (2016: 4) report estimates that $45 \%$ of the EU's renewable energy output in 2050 could be owned by citizens, with $37 \%$ of those being produced by energy collectives, and that $83 \%$ of the EU's households could potentially "become an energy citizen", but their calculations are based on very limited data.

These optimistic projections are overshadowed by an inability of LEI to organise politically, resulting in being overlooked by regulators and policy makers (Roberts 2019). The author also states that the lack of support at a supranational level caused the distribution of LEI to be very uneven across the EU, meaning that citizens across the Union have very different access to invest in and reap the economic benefits of energy transition. In fact, this corroborates the conclusions of Wierling et al. (2018), who mention that developments in the number of LEI in different countries coincide with the development of support schemes at the country level regardless of official EU policy, and that a withdrawal of the said schemes inevitably led to a downturn or a halt of the number of initiatives.

The rising, but still insufficient, share of renewable energy in a country such as the Netherlands, which has favourable conditions for the success of local energy initiatives, should serve as a cautionary tale against placing the burden of a transition to a low-carbon society in groups of concerned and active citizens willing to act and produce their own energy. The promise of a successful energy transition anchored in LEI remains largely unfulfilled in the Netherlands and the EU as a whole. This will probably persist without strong, overarching national and European policies supporting these initiatives.

\section{Conclusions}

In this article, we have discussed how sustainable place shaping can result from co-production between governments and citizens in the context of energy transition. Our findings show that co-production results not only from cooperation between the LEI, governments, private actors, and NGOs, but is also embedded in the cooperative itself. In this sense, co-production can be a site of incubation and multi-scale spatial networking to promote energy initiatives and innovation.

Our assumption was that sustainable place shaping supports place-based development towards sustainability (Roep et al. 2015; Horlings 2018). Our findings indicate that LEI itself are place based, resulting from the conditions found in this study: physical space and physical conditions needed for the production of renewable energy, specific institutional arrangements, place-based assets, people's capacities characteristic for the place, and past collaboration.

Theoretically, the PlaCI model provided a valuable framework to analyse the conditions for collaboration and new arrangements that can support sustainable place shaping. While our findings of our case are not generalisable to the situation of LEI in general—especially considering the very 
favourable conditions the initiative has benefitted fromthe model offers scope for further exploration. Follow-up research will compare the role of institutions towards LEI in different European institutional contexts.

Our findings showed how practices of producing renewable energies are grounded in place-based assets and capacities, and reposition markets on renewable energy by shifting the responsibilities from large private companies to local energy initiatives. Thus, place shaping manifests itself materially (the building of wind turbines), immaterially (via new relations between actors involved), and by establishing new rural-urban relations.

A wind park itself is a 'place', a node in a network, illustrating the relevance of multi-scale relations at multiple levels, constructed over time. In this case, a mix of institutions, their role, and their capacity to collaborate provided an enabling institutional setting, contributing to the success of the wind park. These findings correspond with the literature on the role of institutions in place-based development stating that a region's capacity to innovate requires the right balanced mix of formal and informal institutions.

The trend towards decentralisation of public administration in Western European countries provides opportunities for local and provincial institutions to support LEI. However, on the national level, stronger, long-lasting policies and quantitative goal setting are needed to direct renewable energy production. Without national and European policies setting the main goals and targets, the promise of a successful energy transition anchored in LEI remains largely unfulfilled.

Acknowledgements We are very grateful to the respondents who have been interviewed for this paper.

Funding This project has received funding from the European Union's Horizon 2020 research and innovation program under the Marie Skłodowska-Curie Grant Agreement No. 674962.

\section{Compliance with ethical standards}

Conflict of interest The authors declare no conflict of interest.

Ethics statement SUSPLACE has formulated an ethical policy for the programme. The research project proposal underlying this research has been approved by the hosting university and the ethical committee of SUSPLACE. The respondents involved in the research have signed a letter of consent.

Open Access This article is licensed under a Creative Commons Attribution 4.0 International License, which permits use, sharing, adaptation, distribution and reproduction in any medium or format, as long as you give appropriate credit to the original author(s) and the source, provide a link to the Creative Commons licence, and indicate if changes were made.The images or other third party material in this article are included in the article's Creative Commons licence, unless indicated otherwise in a credit line to the material. If material is not included in the article's Creative Commons licence and your intended use is not permitted by statutory regulation or exceeds the permitted use, you will need to obtain permission directly from the copyright holder.To view a copy of this licence, visit http://creativecommons.org/licenses/by/4.0/.

\section{References}

Albrechts L (2012) Reframing strategic spatial planning by using a coproduction perspective. Plan Theory 12:46-63. https://doi. org/10.1177/1473095212452722

Amin A (2004) Regions unbound: towards a new politics of place. Geogr Ann 86B(1):33-44. https://doi.org/10.111 1/j.0435-3684.2004.00152.x

Ansell C, Gash A (2007) Collaborative governance in theory and practice. J Public Adm Res Theory 18:543-571. https://doi. org/10.1093/jopart/mum032

Arentsen M, Bellekom S (2014) Power to the people: local energy initiatives as seedbeds of innovation? Energy Sustain Soc 4:2. https://doi.org/10.1186/2192-0567-4-2

Baker S, Mehmood A (2015) Social innovation and the governance of sustainable places. Local Environ 20(3):321-334. https://doi. org/10.1080/13549839.2013.842964

Bakker J, Denters B, Oude Vrielink MO, Klok P-J (2012) Citizens' initiatives: how local governments fill their facilitative role. Local Gov Stud 38:395-414. https://doi.org/10.1080/03003 930.2012.698240

Bendell BA (2018) Deep adaptation: a map for navigating climate tragedy. IFLAS Occasional Paper 2. https://www.lifeworth.com/ deepadaptation.pdf. Accessed 7 Aug 72019

Bentley G, Pugalis L (2014) Shifting paradigms: people-centred models, active regional development, space-blind policies and place-based approaches. Local Econ 29(4-5):283-294. https:// doi.org/10.1177/0269094214541355

Biesbroek GR, Swart RJ, van der Knaap WGM (2009) The mitigationadaptation dichotomy and the role of spatial planning. Habitat Int 33(3):230-237. https://doi.org/10.1016/j.habitatint.2008.10.001

Bock BB (2012) Social innovation and sustainability; how to disentangle the buzzword and its application in the field of agriculture and rural development. Stud Agric Econ 114:57-63. https://doi. org/10.7896/j.1209

Boonstra B, Boelens L (2011) Self-organization in urban development: towards a new perspective on spatial planning. Urban Res Pract 4:99-122. https://doi.org/10.1080/17535069.2011.579767

Borgi V, Van Berkel R (2007) Individualised service provision in an era of activation and new governance. Int J Sociol Soc Policy 27:413-424. https://doi.org/10.1108/01443330710822101

CE Delft (2016) The potential of energy citizens in the European Union. https://www.ce.nl/publicatie/the_potential_of_energy_ citizens_in_the_european_union/1845. Accessed 17 May 2019.

Coenen FHJM, Hoppe T, Chalkiadakis G, Tsoutsos T, Akasiadis C (2017) Exploring energy saving policy measures by renewable energy supplying cooperatives (REScoops). In: ECEEE 2017 summer study on energy efficiency: consumption, efficiency and limits, pp 381-391 (ISBN 978-91-983878-1-0)

Coy PG, Hedeen T (2005) A stage model of social movement cooptation: community mediation in the United States. Sociol Q 46:405-435. https://doi.org/10.1111/j.1533-8525.2005.00020.x

Cresswell T (2004) Place; a short introduction. Blackwell Publishing, Malden (ISBN: 978-1-405-10671-9)

De Boer J, Zuidema C, Van Hoorn A, De Roo G (2018) The adaptation of Dutch energy policy to emerging area-based energy practices. Energy Policy 117:142-150 
De Haan EM (2019) Citizens' initiatives in depopulating rural areas. Understanding success, failure and continuity from multiple perspectives. Ph.D. thesis, University of Groningen, Groningen, The Netherlands. https://hdl.handle.net/11370/7164cf89-f95e-47ffa320-720e7c46d0ee. Accessed 4 Apr 2019

De Moor T (2008) The silent revolution: a new perspective on the emergence of commons, guilds, and other forms of corporate collective action in Western Europe. Int Rev Soc Hist 53(S16):179_ 212. https://doi.org/10.1017/S0020859008003660

Denters B (2016) Community self-organisation: potentials and pitfalls. In: Edelenbos J, Meerkerk I (eds) Critical reflections on interactive governance. Self-organization and participation in public governance. Edwar Elgar Publishing Inc, Northampton, pp 230-253. https://doi.org/10.4337/9781783479078.00016

Derveaux K (2019) Preface. In: Vansintjan D (ed) Mobilising European citizens to invest in sustainable energy: clean energy for all Europeans. Final results-oriented report of the REScoop MECISE Horizon 2020 Project, p. 6

Driessen PPJ, Dieperink C, van Laerhoven F, Runhaar HAC, Vermeulen WJV (2012) Towards a conceptual framework for the study of shifts in modes of environmental governance-experiences from the Netherlands. Environ Policy Gov 22:143-160. https://doi.org/10.1002/eet.1580

Eitan A, Herman L, Fischhendler I, Rosen G (2019) Communityprivate sector partnerships in renewable energy. Renew Sustain Energy Rev 105:95-104

Elzenga H, Schwenke AM (2015) Lokale energiecooperaties: nieuwe spelers in de energie. Bestuurskunde 24(2):17-26

European Commission (2010) Empowering people, driving change: social innovation in the EU. Brussels, Bureau of European Policy Advisers. https://ec.europa.eu/migrant-integration/?actio $\mathrm{n}=$ media. download\&uuid=2A18225B-A4EF-443D-9D074 439D071447D. Accessed 5 Aug 2019

European Commission (2018) The revised renewable energy directive. Office for Official Publications of the European Communities, Luxembourg. https://ec.europa.eu/energy/sites/ener/ files/documents/directive_renewable_factsheet.pdf. Accessed 4 Feb 2019

Eurostat (2019) Renewable energy statistics. https://ec.europa.eu/euros tat/statistics-explained/index.php/Renewable_energy_statistics. Accessed $21 \mathrm{Feb} 2019$

Fraunhofer ISE (2019) Photovoltaics report. https://www.ise.fraunhofer .de/content/dam/ise/de/documents/publications/studies/Photo voltaics-Report.pdf. Accessed 5 Aug 2019

Geels FW (2004) From sectoral systems of innovation to socio-technical systems Insights about dynamics and change from sociology and institutional theory. Res Policy 33:897-920. https://doi. org/10.1016/j.respol.2004.01.015

Guillou M (2019) REScoop MECISE: financial tool for energy communities. In: Vansintjan D (ed) Mobilising European citizens to invest in sustainable energy: clean energy for all Europeans. Final results-oriented report of the REScoop MECISE Horizon 2020 Project, pp 96-99

Hajer M (2011) The energetic society. In search of a governance philosophy for a clean economy. PBL Netherlands Environmental Assessment Agency, The Hague (ISBN 9789078645788)

Hargreaves T, Hielscher S, Seyfang G, Smith A (2013) Grassroots innovations in community energy: the role of intermediaries in niche development. Glob Environ Change 23(5):868-880 (ISSN 0959-3780)

Hasanov M, Zuidema C (2018) The transformative power of selforganization: towards a conceptual framework for understanding local energy initiatives in the Netherlands. Energy Res Soc Sci 37:85-93. https://doi.org/10.1016/j.erss.2017.09.038

Hasanov M, Zuidema C, Horlings LG (2019) Exploring the role of community self-organisation in the creation and creative dissolution of a community food initiative. Sustainability 11(11):3170. https ://doi.org/10.3390/su11113170

Hawkins CV, Wang X (2012) Sustainable development governance: citizen participation and support networks in local sustainability initiatives. Public Works Manag Policy 17(1):7-29. https://doi. org/10.1177/1087724X11429045

Hielscher H, Seyfang G, Smith A (2011) Community innovation for sustainable energy. CSERGE Working Paper 2011-03. https:// hdl.handle.net/10419/48797. Accessed 7 Aug 2019

HIER Opgewekt (2018) Local energy monitor. https://www.hieropgewe kt.nl/local-energy-monitor. Accessed 21 Feb 2019

Hildreth P, Bailey D (2014) Place-based economic development strategy in England: filling the missing space. Local Econ 29(405):363-377. https://doi.org/10.1177/0269094214535712

Hoppe T, Graf A, Warbroek B, Lammers I, Lepping I (2015) Local governments supporting local energy initiatives: lessons from the best practices of Saerbeck (Germany) and Lochem (The Netherlands). Sustainability 7:1900-1931. https://doi.org/10.3390/ su7021900

Horlings LG (2016) Connecting people to place: sustainable placeshaping practices as transformative power. Curr Opin Environ Sustain 20:32-40. https://doi.org/10.1016/j.cosust.2016.05.003

Horlings LG (2017) Transformative socio-spatial planning; enabling resourceful communities. Groningen, Inaugural Lecture. https:// www.inplanning.eu/categories/1/articles/200. Accessed 7 Aug 2019. https://doi.org/10.17418/B.2017.9789491937361

Horlings LG (2018) Politics of connectivity: the relevance of placebased approaches to support sustainable development and the governance of nature and landscape. In: Marsden T (ed) The SAGE handbook of nature. SAGE, London, pp 304-324 (10.4135/9781473983007)

Horlings LG (2019) Sustainable place-shaping: what, why and how. Findings of the SUSPLACE program; Deliverable D7.6 Synthesis report. Wageningen University and Research, Wageningen

Horlings LG, Collinge C, Gibney J (2017) Relational knowledge leadership and local economic development. Local Econ 32(2):95109. https://doi.org/10.1177/0269094217693555

Horlings LG, Roep D, Wellbrock W (2018) The role of leadership in place-based development and building institutional arrangements. Local Econ 33(3):245-268. https://doi.org/10.1177/02690 94218763050

Huybrechts B, Creupelandt D, Vansintjan D (2018) Networking renewable energy cooperatives - the experience of the European Federation REScoop.eu. In: Holstenkamp L, Radtke J (eds) Handbuch Energiewende und Partizipation. Springer VS, Wiesbaden, pp 847-858. https://doi.org/10.1007/978-3-658-09416-4

Igalla M, Van Meerkerk I (2015) De duurzaamheid van burgerinitiatieven Een empirische verkenning. Bestuurswetenschappen 69(3):25-53. https://doi.org/10.5553/Bw/016571942015069 003003

International Panel on Climate Change (2018) Summary for Policymakers. In: Masson-Delmotte V, Zhai P, Pörtner HO, Roberts D, Skea J, Shukla PR, Pirani A, Moufouma-Okia W, Péan C, Pidcock R, Connors S, Matthews JBR, Chen Y, Zhou X, Gomis MI, Lonnoy E, Maycock T, Tignor M, Waterfield T (eds) Global warming of $1.5^{\circ} \mathrm{C}$. An IPCC Special Report on the impacts of global warming of $1.5^{\circ} \mathrm{C}$ above pre-industrial levels and related global greenhouse gas emission pathways, in the context of strengthening the global response to the threat of climate change, sustainable development, and efforts to eradicate poverty. World Meteorological Organization, Geneva (ISBN 978-92-9169-151-7)

Jones M (2009) Phase space: geography, relational thinking, and beyond. Prog Hum Geogr 33(4):487-506. https://doi. org/10.1177/0309132508101599 
Kemp R, Rip A, Schot J (2001) Constructing transition paths through the management of niches. In: Garud R, Karnoe R (eds) Path dependence and creation. R. Lawrence Erlbaum Associates, London, pp 269-299

Lowndes V, Pratchett L, Stoker G (2006) Diagnosing and remedying the failings of official participation schemes: the CLEAR framework. Soc Policy Soc 5:281-291. https://doi.org/10.1017/ S1474746405002988

Marinetto M (2003) Who wants to be an active citizen? The politics and practices of community involvement. Sociology 37:103-120. https://doi.org/10.1177/0038038503037001390

Marschall M (2004) Citizen participation and the neighborhood context: a new look at the coproduction of local public goods. Polit Res Q 57:231-244. https://doi.org/10.1177/106591290405700 205

Marsden T (2013) Sustainable place-making for sustainability science: the contested case of agri-food and urban-rural relations. Sustain Sci 8(2):213-226. https://doi.org/10.1007/s11625-012-0186-0

Massey D (2005) For space. SAGE, Los Angeles (ISBN: 9781412903622)

Meijer M (2018) Community-led government-fed and informal. Exploring planning from below in depopulating regions across Europe. Ph.D. thesis, Radboud Universiteit, Nijmegen. https:// hdl.handle.net/2066/183214. Accessed 4 Apr 2019

Meijerink S, Stiller S (2013) What kind of leadership do we need for climate adaptation? A framework for analyzing leadership objectives, functions, and tasks in climate change adaptation. Environ Plann C Gov Policy 31(2):240-256. https://doi.org/10.1068/ c11129

Miazzo F, Kee T (2014) We own the city. Enabling community practice in architecture and urban planning. Trancityxvaliz, Amsterdam (ISBN: 978-90-78088-91-2)

Moulaert F, Mehmood A (2011) Spaces of social innovation. In: Pike A, Rodríguez-Pose A, Tomaney J (eds) Handbook of local and regional development. Routledge, London, pp 212-225

Moulaert F, MacCallum D, Mehmood A, Hamdouch A (2013) The international handbook on social innovation: collective action, social learning and transdisciplinary research. Edward Elgar, Cheltenham

Movisie (2017) Participatiesamenleving anno 2017: volop kansen. https://www.movisie.nl/artikel/participatiesamenleving-anno2017-volop-kansen. Accessed 5 Aug 2019

Mulder M, Willems B (2019) The Dutch retail electricity market. Energy Policy 127:228-239. https://doi.org/10.1016/j.enpol .2018.12.010

Nesti G (2017) Co-production for innovation: the urban living lab experience. Policy Soc 37:310-325. https://doi.org/10.1080/14494 035.2017.1374692

Nijmegen European Green Capital Programme (2017) Nijmegen European Green Capital Programme. https://ec.europa.eu/environmen t/europeangreencapital/wp-content/uploads/2017/07/NijmegenProgramme.pdf. Accessed 2 May 2019

Ornetzeder M, Rohracher H (2013) Of solar collectors, wind power, and car sharing: Comparing and understanding successful cases of grassroots innovations. Glob Environ Change 23(5):856-867. https://doi.org/10.1016/j.gloenvcha.2012.12.007

Ostrom E (1990) Governing the commons: the evolution of institutions for collective action. Cambridge University Press, New York. https://doi.org/10.1017/CBO9780511807763

Ostrom E (1996) Crossing the great divide: coproduction, synergy, and development. World Dev 24:1073-1087. https://doi. org/10.1016/0305-750X(96)00023-X

Ostrom E (2005) Understanding institutional diversity. Princeton University Press, Princeton (ISBN: 9780691122380)
Ostrom E (2011) Background on the institutional analysis and development framework. Policy Stud J 39:7-27. https://doi.org/10.111 1/j.1541-0072.2010.00394.X

Oteman M, Wiering MA, Helderman J-K (2014) The institutional space of community initiatives for low-carbon energy: a comparative case study of the Netherlands, Germany and Denmark. Energy Sustain Soc 4:11. https://doi.org/10.1186/2192-0567-4-11

Oteman M, Kooij H-J, Wiering MA (2017) Pioneering renewable energy in an economic energy policy system: the history and development of Dutch grassroots initiatives. Sustainability 9(4):1-25. https://doi.org/10.3390/su9040550

Perri 6, Fletcher-Morgan C, Leyland K (2010) Making people more responsible: the Blair governments' programme for changing citizens' behaviour. Polit Stud 58:427-449. https://doi.org/10. 1111/j.1467-9248.2009.00817.x

Roberts J (2019) The impact of liberalisation on citizen participation in the energy transition. In: Vansintjan D (ed) Mobilising European citizens to invest in sustainable energy: clean energy for all Europeans. Final results-oriented report of the REScoop MECISE Horizon 2020 Project, pp 17-19

Rodríguez-Pose A, Di Cataldo M (2015) Quality of governance and innovative performance in the regions of Europe. J Econ Geogr 15:673-706. https://doi.org/10.1093/jeg/lbu023

Roep D, Wellbrock W, Horlings LG (2015) Raising self-efficacy and resilience: collaborative leadership in the Westerkwartier. In: McDonagh J, Nienaber B, Woods M (eds) Globalization and Europe's rural regions. Ashgate, Farnham and Burlington, pp 41-58. 10.4324/9781315585086

Seyfang G, Haxeltine A (2012) Growing grassroots innovations: exploring the role of community-based initiatives in governing sustainable energy transitions. Environ Plan C Gov Policy 30:381-400. https://doi.org/10.1068/c10222

Seyfang G, Smith A (2007) Grassroots innovations for sustainable development: towards a new research and policy agenda. Environ Polit 16:584-603. https://doi.org/10.1080/0964401070 1419121

Smith A (2012) Civil society in sustainable energy transitions. In: Verbong G, Loorbach D (eds) Governing the energy transition: reality, illusion, or necessity. Routledge, New York, pp 181-202

Soares da Silva D, Horlings LG, Figueiredo E (2018) Citizen initiatives in the post-welfare state. Soc Sci 7:252. https://doi.org/10.3390/ socsci7120252

Sorrentino M, Sicilia M, Howlett M (2018) Understanding co-production as a new public governance tool. Policy Soc 37(3):277-293. https://doi.org/10.1080/14494035.2018.1521676

Sotarauta M, Horlings LG, Liddle J (2012) Leadership and change in sustainable regional development. Routledge, London. https:// doi.org/10.4324/9780203107058

Tonkens EH (2008) De bal bij de burger. Burgerschap en publieke moraal in een pluriforme, dynamische samenleving. Vossiuspers Universiteit van Amsterdam, Amsterdam. https://doi. org/10.5117/9789056295370

Ulug C, Horlings LG (2019) Connecting resourcefulness and social innovation: exploring conditions and processes in community gardens in the Netherlands. Local Environ 24(3):147-166. https ://doi.org/10.1080/13549839.2018.1553941

Van Aalderen N (2018) Accommodating a citizen-led energy transition. https://www.inplanning.eu/categories/12/articles/221. Accessed 5 Aug 2019

Van Dam R, Salverda I, During R (2014) Strategies of citizens' initiatives in the Netherlands: connecting people and institutions. Crit Policy Stud 8:323-339. https://doi.org/10.1080/19460 171.2013.857473

Van de Wijdeven TMF, de Graaf LJ (2014) Kernkracht: over doedemocratie in het landelijke gebied. Tilburgse School voor Politiek en Bestuur, Tilburg 
Van der Schoor T, Scholtens B (2015) Power to the people: local community initiatives and the transition to sustainable energy. Renew Sustain Energy Rev 43:666-675. https://doi.org/10.1016/j. rser.2014.10.089

Varró K, Lagendijk A (2013) Conceptualizing the region-in what sense relational? Reg Stud 47(1):18-28. https://doi. org/10.1080/00343404.2011.602334

Verhoeven I, Tonkens EH (2013) Talking active citizenship: framing welfare state reform in England and the Netherlands. Soc Policy Soc 12:415-426. https://doi.org/10.1017/S1474746413000158

Verschuere B, Brandsen T, Pestoff V (2012) Co-production: the state of the art in research and the future agenda. Voluntas 23:10831101. https://doi.org/10.1007/s11266-012-9307-8

Wallace-Wells D (2019) The uninhabitable earth. Tim Duggan Books, New York

Warren ME (2001) Democracy and association. Princeton University Press, Princeton

WCED (1987) Our common future. World commission on environment and development. University Press, Oxford, Oxford

Wellbrock W (2013) Well-working operational interfaces; a key to more collaborative modes of governance. PhD Thesis, Wageningen, Wageningen University \& Research

Westley FR, Tjornbo O, Schultz L, Olsson P, Folke C, Crona B, Bodin Ö (2013) A theory of transformative agency in linked socialecological systems. Ecol Soc 18(3):27. https://doi.org/10.5751/ ES-05072-180327
Whitaker G (1980) Coproduction: citizen participation in service delivery. Public Adm Rev 40:240-246. https://doi.org/10.2307/97537 7

Wierling A, Schwanitz V, Zeiß J, Bout C, Candelise C, Gilcrease W, Gregg J (2018) Statistical evidence on the role of energy cooperatives for the energy transition in European countries. Sustainability 10:3339. https://doi.org/10.3390/su10093339

Wittmayer JM, Schäpke N (2014) Action, research and participation: roles of researchers in sustainability transitions. Sustain Sci 9(4):483-496. https://doi.org/10.1007/s11625-014-0258-4

Woods M (2011) Regions engaging globalization: a typology of regional responses in rural Europe. In: Paper presented to the Anglo-American-Canadian rural geographers quadrennial conference, July 2011, Manitoba, Canada

Woods M (2015) Territorialization and the assemblage of rural place: examples from Canada and New Zealand. In: Dessein J, Battaglini E, Horlings LG (eds) Cultural sustainability and regional development: theories and practices of territorialisation. Series on cultural sustainability. Routledge, London, pp 29-42. https:// doi.org/10.4324/97813157374

Publisher's Note Springer Nature remains neutral with regard to jurisdictional claims in published maps and institutional affiliations. 